\title{
Evaluation of Citizen Partner Program in State High School 13 Surabaya
}

\author{
Nafi' Sayyidatul Husna ${ }^{1 a}$, Maria Veronika Roesminingsih ${ }^{1 b}, \&$ Warih Handayaningrum ${ }^{1 c}$ \\ 1Department of Education Management, Postgraduate Program of State University of Surabaya, Surabaya, Indonesia \\ a nafi.17070845026@mhs.unesa.ac.id, b Prof.MV.Roesminingsih@unesa.ac.id, c Dr.Warih.Handayaningrum@unesa.ac.id \\ Dr.Mudjito@unesa.ac.id, cDr.Endang.Purbo@unesa.ac.id \\ ${ }^{*}$ Corresponding Author \\ Phone Number: [+6281259493024]
}

How to Cite: Husna, N., S., Roesminingsih, M., V.,\& Handayaningrum, W, (2020). Evaluation of Citizen Partner Program in State High School 13 Surabaya. International Journal for Educational and Vocational Studies, 2(2), 165-168. DOI: https://doi.org/10.29103/ijevs.v2i2.2282

\section{ARTICLE HISTORY}

Received:14 December 2019

Revised: 28 January 2020

Accepted: 6 February 2020

\section{KEYWORDS}

Program evaluation;

Citizen parthners;

Free education;

\section{ABSTRACT}

The development of education in Indonesia must use at least four basic strategies. Namely, The first is equitable distribution of opportunities for education; the second is relevance; the third is quality improvement, and the fourth is efficiency. Generally, this strategy can be divided into two dimensions, namely education improvement and equity. Development of quality improvement is expected to increase the efficiency, effectiveness and productivity of education. "Dimensions of educational equity are expected to provide equal opportunities in obtaining education for all school ages" (Amri, 2013: 68). In realizing distribution of opportunities to obtain education, Surabaya implements a program for acceptance of new students through the path of community partners. The emergence of this policy is also a proof of the government's commitment in carrying out the mandate of the Constitution regarding $20 \%$ of the budget for education. This study uses an evaluation research with a qualitative approach. The main data source in this study was obtained by snowball sampling. Data collection techniques in this study used three techniques, namely observation, interviews, and documentation. State High School 13 Surabaya is one of the schools implementing a citizen partner program. The conclusion from this study states that the implementation of the citizen partner program in State High School 13 Surabaya has not yet been reached because of the discovery of elements of nepotism and lack of socialization resulting in one student having not been affected by the community partner program.

This is an open access article under the CC-BY-SA license.

\section{INTRODUCTION}

Education can be considered as a dynamic process in an effort to develop human resources in accordance with their role in the future with various characteristics contained therein. As stated in the functions and objectives of the Law of the Republic of Indonesia Number 202003 concerning National Education System Chapter II Article 3 which states that "National education functions to develop dignity in the context of educating the nation, aiming at developing the potential of students to be human beings of faith and devoted to God Almighty, noble, healthy, knowledgeable, capable, creative, independent and become democratic and responsible citizens ".

The development of education in Indonesia must use at least four basic strategies. Namely, The first is equitable distribution of opportunities for education; the second is relevance; the third is quality improvement, and the fourth is efficiency. Generally, this strategy can be divided into two dimensions, namely education improvement and equity. Development of quality improvement is expected to increase the efficiency, effectiveness and productivity of education. "Dimensions of educational equity are expected to provide equal opportunities in obtaining education for all school ages" (Amri, 2013: 68).

The education system in Indonesia although it has already had a strong foundation in the constitution, but in reality it cannot be implemented as expected. These problems include educational equity, the relevance of education as well as the effectiveness and efficiency of education which will lead to the problem of education. The problem of equal distribution of education leads to funding or financing policies incurred for all needs in the teaching and learning process, for example providing direct scholarships to students who are underprivileged and in realizing equal opportunities for obtaining education of outstanding students, providing subsidies for schools to finance students from underprivileged families. The issue of the effectiveness and efficiency of education 
concerns the implementation of the national education system and concerns how the potential of very limited educational resources can be optimized.

Alejandro Cid And Ana I. Balsa. 2018.

The Provincial Government of East Java realizes equal opportunity to obtain education for underprivileged citizens. The Provincial Government of East Java cooperates with the East Java Provincial Education Office to carry out a program for accepting new students through the path of community partners. The education office cooperates with several parties in the socialization, implementation, and coordination of the program for accepting new students through the path of community partners in order to run optimally, remembering that the implementing human resources of the education office are limited. The emergence of this policy is also a proof of the government's commitment in carrying out the mandate of the Constitution regarding $20 \%$ of the budget for education. Citizen partner programs in East Java Province have been regulated in the regional regulation of East Java Province Number 112017 regarding the Implementation of High School / Vocational Education. State High School 13 Surabaya is one of the schools implementing a citizen partner program. In the implementation of the Community Partner Program there are several problems regarding the falsification of economic status until the realization of the Community Partner Program does not accommodate the needs of poor students. This encourages researchers to conduct research in State High School 13 Surabaya.

\section{MATERIALS AND METHODS}

The research on evaluating citizen partner programs in State High School 13 Surabaya uses a qualitative approach. Qualitative research is research that aims to analyze, understand and express phenomena, events, activities, social, attitudes, and perceptions of thought individually or in groups. The purpose of using qualitative research is to describe, uncover, and explain. So, the results in this study analyze the level of achievement of the citizen partner program in State High School 13 Surabaya.

This study uses evaluation research with qualitative methods that focus on case studies, because case studies are research conducted in a system of programs, activities, events, or groups of individuals who are bound by a particular place, time, or bond directed to collect data, take meaning, get a case understanding.

Research subjects are people used as sources of information to uncover facts in the field (Arikunto, 2006: 145). Determination of research subjects or samples in qualitative research is chosen to obtain maximum information not based on statistical calculations.

The data sources in this study were divided into two, namely: 1) the main data source obtained in the form of words or verbally and the behavior of the subject (informant) and 2) the secondary data source obtained from photographs, documents and objects. used as a complement to the main data source (Arikunto, 2010: 130). The main data source in this study was obtained by snowball sampling to select and take samples through the process of rolling from one respondent to another respondent, while secondary data sources in the form of documents, such as books, articles, scientific journals, letters or archives at State High School 13 Surabaya. Data collection techniques in this study used three techniques, namely observation, interviews, and documentation (Bogdan and Biklen, 2003: 38).

\section{RESULTS AND DISCUSSIONS}

State High School 13 Surabaya is one of the favorite high schools in Surabaya that has implemented a partner community program for disadvantaged students based on the priority of the school zone of origin with the student's residence.

\section{A. The implementation of the Citizen Partner Program}

Equitable education in the empiricism approach emphasizes the combination of methodology and substance. A lot of important research was born from the empiricism approach. In the empiricism approach, educational inequality occurs due to differences in interests between social classes. One example is the status quo maintained by the elite, but unlike the populists who continue to struggle to get educational opportunities.

At present educational equity is developing into two. This is like Tilaar's statement (1993: 26): firstly the empiricism approach and quantitative research which have spent a lot of their output costs can be directed to analyze the role of education in improving its quality by reducing or maintaining structural educational equity. The concept of egalitarianism on an ongoing basis was born along with this type of research in the field of education. Secondly the applied research education sector is in the form of quasi experiment.

Registration of new students in the path of citizen partners each year only accepts students at 5\% according to the quota. The goal of the Citizen Partner Program is to provide opportunities for underprivileged citizens to receive education in both public and private schools to reduce the dropout rate, while the benefit is economically to reduce the burden on the costs of underprivileged families to receive education, and the target of the Citizen Partner Program is underprivileged families.

Changes in education management policies at the secondary and vocational education levels of the city government on the provincial government as stipulated in regional regulation number 11 of 2017 have an impact on financial management. The cost of education at the Senior High School/ Vocational High School level for the community partner pathway since the transfer of management of the Senior High School from the city 
government to the province in 2017 students receiving the Citizen Partner Program are required to pay 150 thousand rupiahs although in practice State High School 13 only requires paying as much as they can.

Education in the long term aims to create a more prosperous and equitable life of the people born and inward in a fair and equitable manner, a more solid national culture which is reflected in enhancing Indonesian civilization, dignity and human dignity, and strengthening the identity of the nation's personality. In the development of the national education system, it must be paid to the relationship between education and social change, the economic, political and state order. The logic of development has the same and universal side, namely that development starts from growth. The growth is then divided or leveled. Without growth, nothing is flattened except poverty. Educational equity relates to education indicators.

The mechanism for accepting new students through the partner path of prospective recipient residents must come to school with a photocopy of the SKTM, SKHUN and the original KK. Then the school will input the data and conduct a survey to the homes of the Citizen Partner Program registrants. Partner program socialization is carried out from the village level and even RW level to conduct socialization to the community. In addition, the Citizen Partner Program is disseminated through several media including mass media, radio and websites.

For the verification process of prospective recipients that have been examined by the school or verification team, prospective recipients of the Citizen Partner Program will be seen and checked the poor certificate and SKHUN scores and surveyed. After it has been announced, students have received a re-registration process. If not to do the re-registration process at the determined time, students are considered resigned and cannot be accepted through any path.

\section{B. The Level Of Achievement Of The Community Partner Program}

The level of achievement of a program is a systematic and continuous process to assess the success and failure of implementation in accordance with the programs, policies, targets and objectives that have been set in realizing the mission and vision. Generally, the level of achievement has direct implications for the community as well as subjective satisfaction is more difficult to measure (Schiavo-Campo and Sundaram, 2000). The level of achievement can be done using indicators of achievement obtained from a policy that has been made. Measuring the achievement of the program is done by comparing the level of achievement of the targets set by the policy with the implementation of a program in the field.

The level of achievement of the community partner program can be seen from three aspects namely input, process and output. In terms of input, it has not been successful because nepotism is still found and the lack of socialization has resulted in one student who has not been affiliated with a citizen partner program. Whereas in terms of the process of Stufflebeam (2003: 2) stated: Process evaluations assess the implementation of plans to helf staff carry out activities and later help the board group of users judge program performance and interpretation outcomes. It means evaluating the process of assessing how effective the implementation of activities through comparison between planning and activities in the field. In this study, the level of achievement was seen from the aspect of process evaluation (could be called monitoring) with regard to how far the implementation of the community partner program has been running effectively. Process evaluation refers to what activities are carried out in the program, who is appointed as the person in charge of the program, when the activity will be completed. The learning process of student partner citizens is able to participate in learning activities in class. No one is dropped out of school, even among them; there are students which have achievements in academic and non-academic fields.

Process evaluation is an evaluation designed and applied in the practice of implementing activities, identifying procedural problems both the management of events and activities. Every activity is monitored for changes occurring honestly and carefully. Recording is useful to determine follow-up improvements and determine the strengths and weaknesses or linkages of the program with the results found. Process evaluation is directed at the extent to which the activities carried out in the program have been carried out in accordance with the plans and guidelines set. In the implementation of the evaluation process in terms of learning, student partner citizens are able to follow learning activities in class. The learning process of student partner citizens is able to participate in learning activities in class. No one is dropped out of school, even among them; there are students which have achievements in academic and non-academic fields because the students have their respective talents and interests. Counseling teachers from State High School 13 stated that academic and non-academic achievements of 15 student partners were $30 \%$ of students had an achievement in the non-academic field and $10 \%$ of students had academic achievements. This shows that all students' partner citizens have different characteristics which cannot be equated to have poor academic grades.

Mackay (2008) describes performance indicators as a measure of inputs, activities, outputs, results and impacts of government activities. Performance measurement includes the level of target achievement (planned level of achievement) of each group of activity performance indicators and the level of target achievement (planned level of achievement) of each target group specified in the work plan document. Measurement of target achievement level is based on data from the measurement of activity performance. In terms of output, the level of student achievement could be seen through the results of graduates who nearly $60 \%$ entered State Universities $35 \%$ 
entered Private Universities and the rest worked. The Citizen Partner Program also has a positive impact on reducing the dropout rate in Surabaya. The higher the APK means that more school-age children attend school in an area or more and more children outside the age group attend school at a certain level of education.

\section{The Obstacle Of The Community Partner Program}

According to Tyler in Arikunto (2009: 5), program evaluation is the process to know whether educational goals have been realized. Furthermore, according to Cronbach and Stufflebeam in (Arikunto 2009: 5), program evaluation is an effort to provide information to be conveyed to decision makers. Constraints to the community partner program

In the input aspect has not been successful because the discovery of nepotism and of the socialization program, the community partner program has not been reached, so there are underprivileged students who are not affected by the education office due to lack of information about the community partner program and

Furthermore, the criteria for being underprivileged in the community partner program are still no definite rules. In terms of the process the obstacle is the academic gap between students who register through the regular path and the citizen partner pathway; this can be seen from the average NUN value that is 20 . In terms of output results of graduates of which almost $60 \%$ enter State Universities, $35 \%$ enter Private Universities and the rest work. The Citizen Partner Program also has a positive impact on reducing the dropout rate in Surabaya. The higher the APK means that more school-age children attend school in an area or more and more children outside the age group attend school at a certain level of education.

\section{CONCLUSION}

Based on the results of the discussion described above, it can be concluded that the evaluation of citizen partner programs in State High School 13 Surabaya in terms of input has not been successful because the discovery of nepotism and the lack of socialization have resulted in one student who has not been affiliated with a community partner program. While in terms of the learning process of students, partner citizens are able to participate in learning activities in class. No one is dropped out of school, even among them; there are students which have achievements in academic and non-academic fields because the students have their respective talents and interests. Counseling teachers from State High School 13 stated that academic and non-academic achievements of 15 student partners were $30 \%$ of students had an achievement in the non-academic field and $10 \%$ of students had academic achievements. This shows that all students' partner citizens have different characteristics which cannot be equated to have poor academic grades.

In addition to academic and non-academic achievements in terms of outcomes or products the level of student achievement, it can be seen through the results of graduates of which almost $60 \%$ enter State Universities, $35 \%$ enter Private Universities and the rest work. The Citizen Partner Program also has a positive impact on reducing the dropout rate in Surabaya. The higher the APK means that more school-age children attend school in an area or more and more children outside the age group attend school at a certain level of education.

\section{REFERENCES}

Alejandro Cid And Ana I. Balsa. (2018). A Randomized Impact Evaluation Of a Tuition-Free Private School Targeting Low Income Student in Uruguay.

Andrews et al. (2010) separately examined effects for students from low-income families (as captured by student-reported income on the ACT survey).

Arikunto, Suharsimi. (2008). Prosedur Penelitian. Jakarta: Rineka Cipta

Badan Pusat Statistik. 2016-2017. Statistik Angka Kemiskinan di Kota Surabaya Tahun 2016-2017. http://bps.go.id.

Bogdan, Robert C. dan Biklen Kopp Sari, (1982), Qualitative Research for Education: An Introduction to Theory and Methods. Allyn and Bacon, Inc.: Boston London.

Chambers, Robert (1983), Rural Development : Putting the last First, Longman, London.

Coleman. (1990). Equality and Achiecement in Education. Westview Press.

Danim, Sudarwan. (2010). Pengantar Kependidikan. Bandung : Alfabeta

Depdiknas. (2003). UU No. 20 Tahun 2003 tentang Sistem Pendidikan Nasional. Jakarta: Biro Hukum dan Organisasi Setjen Depdiknas.

H.A.R. Tilaar. (2002). Membenahi Pendidikan Nasional. Jakarta: PT. Rineka Cipta.

Mark Bray, Magda Nutsa Kobakhidze \& Ora Kwo. 2018. Policy Brief Supplementary Tuition and the Roles of Teachers in Myanmar

Meredith Savary Billings. (2018). Free College For All: The Impact Of Promise Programs On College Access And Success.

Miles, Matthew B dan A. Michael Huberman. (1992). Analisis Data Kualitatif. Terjemahan Tjetjep Rohendi Rohidi. UI Press, Jakarta.

Schultz, Theodore, W. (1961). "Investment in Human Capital". The American Economics Review, No. 51.

Sergiovanni, Thomas J. (1987). Educational Govermence and Administration. New Jersey: Prentice Hall inc.

Stufflebeam, Daniel L dan Shinfield, Antony J. (2007). Evaluation Theory, Models and Applications. San Francisco: Jossey-Bass.

Sugiyono. (2018). Metodologi Penelitian Kuantitatif, Kualitatif dan R \& D. Bandung:CV Alfabeta.

Susan B. Neuman \& Donna Celano. (2006). The knowledge gap: Implications of leveling the playing field for low-income and middle income children.

Syam, Noor. (1986). Filsafat Pendidikan dan Dasar Filsafat Kependidikan Pancasila. Surabaya: Usaha Nasional.

Welsh,T dan McGinn,N. (2003). Desentralisasi Pendidikan. Terjemahan Ahmad Syahid. Jakarta: Logos. 